\title{
The role of religion in transplanting liver in Indonesia
}

\author{
Mahyuddin MAHYUDDIN ${ }^{* 1}$, Kadriah KADRIAH $^{2}$ \\ 'Sociology Department, Institut Agama Islam Negeri Parepare, Parepare, Indonesia \\ ${ }^{2}$ Department of Public Health, Al Asyariah Mandar University, Polewali, Indonesia
}

Introduction: This study aims to investigate the role of religion on individual decisions to donate body organ especially liver.

Methods: This study used a juridical normative method that was analytical description of law sociology and normative qualitative analysis of secondary data by examining Muhammadiyah and Nahdatul Ulama agreements as well as the guidance of an order person of The Indonesian Council of Ulama in Indonesia.

Results: The results of this study indicate that (a) The agreement of Islamic organizations about whether or not organ transplants have given new hope to liver patients in which the scholars recommend transplantation as long as the benefits obtained are greater and do not endanger the person who receives (recipient) with the provisions of the organ in pairs (kidneys, eyes, feet, ears), not the only organs, such as the liver, brain, or heart. (b) The largest Islamic organizations in Indonesia such as MUI, NU and Muhammadiyah in general allowed this practice as long as they followed the provision of the shariah rules (Islam law). (c) Altruism has encouraged the behavior of Muslim liver donors to help other humans, especially fellow Muslims. The other hand, they was not receive money for their action.

Conclusions: In the past, religion became an inhibitor of liver transplant in Indonesia. However, now religion has a significant role in transplanting of body organ including liver donor. There have been many agreements and consensus of scholars (fatwa of ulama) from various conferences, institutions, Islamic organizations that allow the practice of liver transplant. 